\title{
Response of Bread Wheat (Tritcum aestivum L.) to Nitrogen after Major Leguminous Crops Rotation in Tigray, Northern Ethiopia
}

\author{
Bereket Haileselassie ${ }^{1,2}$, Sofonyas Dargie ${ }^{1^{*}}$, Mehretab Haileselassie $^{1}$, \\ Fisseha Hadgu ${ }^{1}$ and Medhn Berhane ${ }^{1}$ \\ ${ }^{1}$ Mekelle Soil Research Center, Tigray Agricultural Research Institute, P.O. Box: 1070, Mekelle, Ethiopia \\ ${ }^{2}$ School of Natural Resources Management and Environmental Sciences, Haramaya University, \\ P.O. Box: 138, Dire Dawa, Ethiopia.
}

\begin{abstract}
Crop rotation is a common practice in the study area, but there is no enough information on the specific rate of nitrogen to be applied after legumes for wheat production. Hence, on farm field experiments were conducted to determine the amount of nitrogen fertilizer rates needed for bread wheat after chick pea, grass pea, fababean and field pea precursor crops. The field experiments were conducted during 2014 main cropping season at Hawzien after chick pea and grass pea and at Emba Alaje after fababean and field pea precursor crops. The experiment consists of six nitrogen rates $\left(0,11.5,23,34.5,46\right.$ and $\left.69 \mathrm{~kg} \mathrm{Nha}^{-1}\right)$ laid in a RCBD with three replications. Phosphorus, sulfur and potassium fertilizers were also applied as basal for all plots at sowing. Surface soil samples were collected before planting and analyzed for selected soil properties. Soil analysis result of the experimental sites revealed that total nitrogen content (\%) of the soil after chickpea-wheat (0.0695), grass pea-wheat (0.067), fababean-wheat (0.074) crop rotation were categorized under low range and after field pea-wheat (0.102) under medium range. Application of nitrogen had significantly increased grain and straw yield at Hawzien district after chick pea and grass pea precursor crops. At Emba-Alaje the highest grain yield was recorded on plots treated with $69 \mathrm{~kg} \mathrm{~N} \mathrm{ha}^{-1}$ $\left(6242 \mathrm{~kg} \mathrm{ha}^{-1}\right)$. Grain and straw yields of wheat increased up to a rate of $46 \mathrm{~kg} \mathrm{~N} \mathrm{ha}^{-1}$ after fababean at Emba-Alaje district. There is no significant difference in grain and straw yields of wheat due to application of nitrogen after field pea crop rotation. In Hawzien the highest agronomic efficiency after chick pea and grass pea was recorded from plots treated with 46 $\mathrm{kg} \mathrm{N} \mathrm{ha}^{-1}$ and $34.5 \mathrm{~kg} \mathrm{~N} \mathrm{ha}^{-1}$, respectively. In Emba Alaje the highest agronomic efficiency after faba bean and field pea was recorded from plots treated with $11.5 \mathrm{~kg} \mathrm{~N} \mathrm{ha}^{-1}$ and $23 \mathrm{~kg}$ $\mathrm{N} \mathrm{ha}^{-1}$, respectively. At Hawzien, the partial budget analysis revealed that application of 46 $\mathrm{kg} \mathrm{N} \mathrm{ha}^{-1}$ for bread wheat after chick pea and grass pea was economical with $1545 \%$ and $796 \%$ marginal rate of return, respectively. At Emba Alaje, the partial budget analysis revealed that application of $34.5 \mathrm{~kg} \mathrm{~N} \mathrm{ha}^{-1}$ for bread wheat after fababean was economical with $895 \%$ marginal rate of return. It could be concluded that application rate of $\mathrm{N}$ for wheat after leguminous crops should consider initial soil $\mathrm{N}$ and precursor crop.
\end{abstract}

Article Information

Copyright@2016 STAR Journal, Wollega University. All Rights Reserved.

\author{
Article History: \\ Received : 06-01-2016 \\ Revised : 14-03-2016 \\ Accepted : 20-03-2016
}

Keywords:

Crop rotation

Nitrogen

Grass pea

Chick pea

Fababean

Wheat

${ }^{*}$ Corresponding Author:

Sofonyas Dargie

E-mail:

sofifidel97@gmail.com

\section{INTRODUCTION}

Wheat is one of the major cereal crops grown in Ethiopia. Wheat is ranked fourth of all cereals, based on area of production (more than 1.6 million hectare) and third based on total production (more than 3.9 million tons) (CSA, 2014). Although wheat is the most important cereal crop in Ethiopia, the national yield has remained low at 2.24 tha-1 (CSA, 2014).

Low soil fertility and slow progress in developing wheat cultivars with durable resistance to disease are considered the most important constraints limiting wheat production in Ethiopia (Demeke and Marcantonio, 2013). Soil fertility depletion is a key problem of cereal production in Ethiopia. Low soil nitrogen $(\mathrm{N})$ is often the major factor limiting crop productivity. Application of inorganic nitrogen fertilizer, crop rotation and intercropping are some of the management practices.

Crop rotation is an integral part of the crop production system. A well planned cropping sequence will reduce insect, pest, disease, ameliorate soil structure, improve organic matter levels, prevents proliferation of weeds and consequently increase the crop yield. The general purposes of rotations are to improve or maintain soil fertility, reduce erosion, reduce the risk of weather damage, reduce reliance on agricultural chemicals and increase net profits (Bauman et al., 2000). Arshad et al. (1998) reported that the benefits of crop rotation as 


\section{Bereket Haileselassie et al.,}

compared to a mono cropping of wheat are increased grain and above ground dry matter yields. Crop rotation enhances soil nitrogen which plays a key role in achieving qualitatively and quantitatively high yields.

Giller (2001) observed that legumes can fix substantial amounts of atmospheric N2, which allows them to be grown in $\mathrm{N}$-impoverished soils without fertilizer or $\mathrm{N}$ inputs. Legume crops leave $\mathrm{N}$-rich residues and improve soil properties that can boost the yield of subsequent crops. The indirect effects related to improved soil properties impacted positively corn and wheat yield and $\mathrm{N}$ nutrition (Adrian et al., 2015).

Farmers in the mid-highlands and highlands of Ethiopia are well aware of the importance of crop rotation to replenish soil fertility and skill-fully used this option (Bereket et al., 2011). Depending on agro-ecology, farmers in Hawzien grow legumes such as chick pea and grass pea and in Emba Alaje grow fababean and field pea as rotation crop with cereals to improve soil fertility, consequently to improve productivity of cereals. Farmers usually reduce the $\mathrm{N}$ requirement of next cereal crop after legume at both sites. However the $\mathrm{N}$ rate required after a specific legume crop for wheat is not well studied in Ethiopia specifically in northern Ethiopia. Therefore a study was conducted to evaluate the nitrogen requirement of wheat after chick pea, grass pea, fababean and field pea precursor leguminous crops in Tigray, Northern Ethiopia.
Sci. Technol. Arts Res. J., Jan-March 2016, 5(1): 9-15

\section{MATERIALS AND METHODS}

On farm field experiments were conducted at districts of Hawzien and Emba Alaje in 2014. Two experiments were conducted at Hawzien district after precursor crops of grass pea and chick pea each in two sites. Two experiments were conducted at Emba-Alaje district after precursor crops of fababean and field pea each in one site. At Hawzien, Siluh Tabia the coordinate ranges from $39^{\circ} 27^{\prime} 20^{\prime \prime}$ to $39^{\circ} 27^{\prime} 30^{\prime \prime}$ latitude and $13^{\circ} 15^{\prime} 16^{\prime \prime}$ to $13^{\circ}$ 59' 90" longitude. At Emba Alaje, Ayba Tabia the coordinate ranges from $39^{\circ} 29^{\prime} 54^{\prime \prime}$ to $39^{\circ} 37^{\prime} 25^{\prime \prime}$ latitude and $12^{\circ} 51^{\prime} 50^{\prime \prime}$ to $12^{0} 54^{\prime} 54^{\prime \prime}$ longitude (Figure 1).

The experiment consists of six nitrogen treatments: 0 , 11.5, 23, 34.5, 46 and $69 \mathrm{~kg} \mathrm{Nha}^{-1}$. The design was Randomized Complete Block Design with three replications in a plot size of $3 \mathrm{~m}$ by $4 \mathrm{~m}$. Each treatments were supplied with basal application of phosphorous, potassium and sulfur at rates of $69 \mathrm{~kg} \mathrm{P}_{2} \mathrm{O}_{5} \mathrm{ha}^{-1}, 80 \mathrm{~kg}$ $\mathrm{K}_{2} \mathrm{O} \mathrm{ha}^{-1}$ and $30 \mathrm{~kg} \mathrm{~S} \mathrm{ha}^{-1}$. Nitrogen, phosphorus, potassium and sulfur were applied in the form of urea, Triple Super Phosphate (TSP), potassium chloride and calcium sulfate, respectively. Phosphorus, potassium, sulfur and half of the nitrogen rates were applied at planting. The remaining half of the nitrogen rates were applied during tillering. The wheat varieties used in these experiments were Kekeba for the distrcit Hawzien and Danda for the district Emba-Alaje and was planted at a rate of $150 \mathrm{~kg} \mathrm{ha}^{-1}$ in row planting.

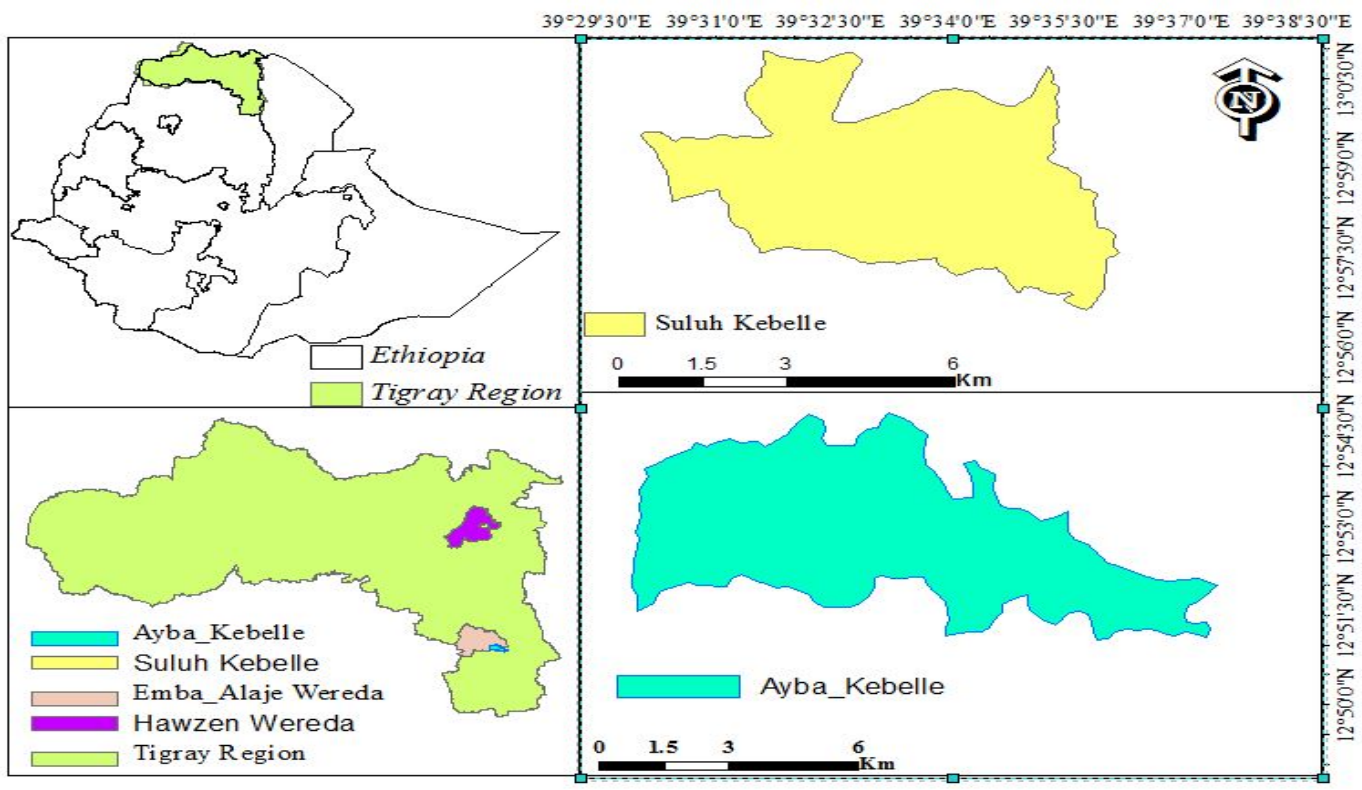

Figure 1: Map of the study sites

\section{Soil Analysis}

The initial experimental soils $(0-20 \mathrm{~cm})$ were analyzed for texture, organic carbon, total nitrogen, CEC, available $\mathrm{P}, \mathrm{pH}$. The methods used for samples physicochemical analysis were pH (Jackson, 1967), organic carbon [modified Walkley and Black method (Jackson, 1967)], texture [hydrometer method procedure of Bouyoucos (Day, 1965), available phosphorous (Olsen et al., 1954), total nitrogen by Kjeldehal method (Bermner and Mulvaney, 1982) and CEC by Neutral ammonium acetate method (Black, 1965).

\section{Data Collection}

Plant height, head length, straw yield and grain yield of wheat for all experimental sites were collected following the standard procedure. Above ground biomass from whole plots were sun-air dried before weighing. The spikes were threshed and cleaned and grain yield was weighed. The straw yield was calculated by subtracting grain yield from the above ground biomass. 


\section{Bereket Haileselassie et al.,}

\section{Agronomic Efficiency of Nitrogen}

Agronomic $\mathrm{N}$ use efficiency $\left(\mathrm{kg} \mathrm{kg}^{-1}\right)=\left(\frac{\mathrm{Gf}-\mathrm{GU}}{\mathrm{Na}}\right)$

Where;

$\mathrm{Gf}$ is the grain yield in the fertilized plot $(\mathrm{kg})$

$\mathrm{Gu}$ is the grain yield in the unfertilized plot $(\mathrm{kg})$

$\mathrm{Na}$ is the quantity of $\mathrm{N}$ applied $(\mathrm{kg})$

\section{Data Analysis}

Generated data were subjected to analysis of variance. All analysis was performed with SAS statistical software package (SAS, 2002). Marginal rate of return (MRR) was calculated as the change in net revenue (NR) divided by the change in total variable cost (TVC) of the successive net revenue and total variable cost levels (CIMMYT, 1988). Daily labor costs were calculated by assuming 60 ETB per person and revenue was calculated by considering the prevailing market price which is 11 ETB per $\mathrm{kg}$ of grain. The cost of urea was 1125.57 ETB per $100 \mathrm{~kg}$ according to Enderta Union.
Sci. Technol. Arts Res. J., Jan-March 2016, 5(1): 9-15

\section{RESULTS AND DISCUSSION}

\section{Soil Properties before Planting}

The chemical and physical property of the soils of the experimental sites after the precursor legume crops is indicated in Table 1. Textural class of Hawzien sites was sandy loam and clay for Emba Alaje. According to FAO (2000) the preferable $\mathrm{pH}$ ranges for most crops and productive soils are from 4 to 8 . Thus, the soil $\mathrm{pH}$ of the experimental sites were within the range for productive soils. According to Tekalign (1991) rating of soil $\mathrm{pH}$, the $\mathrm{pH}$ of soils of Hawzien was moderately acidic and slightly acidic to neutral in Emba Alaje. The organic carbon content of soils of the experimental sites was very low for Hawzien sites and low in Emba Alaje District (Tekalign, 1991). According to Birhanu (1980) total nitrogen content at both sites were low. Available phosphorous (Olsen P) for fababean- wheat and chickpea- wheat crop rotation was medium and for grass pea -wheat and field pea wheat crop rotation was high (Olsen, 1954). According to Landon (1991) rating, CEC was medium to high in Hawzien and very high in Emba Alaje.

Table 1: Surface $(0-20 \mathrm{~cm})$ soil properties of experimental sites after leguminous precursor crops

\begin{tabular}{lcccc}
\hline & \multicolumn{2}{c}{ Hawzien } & \multicolumn{2}{c}{ Emba-Alaje } \\
\hline \multicolumn{1}{c}{ Parameters } & Chick Pea & Grass Pea & Fababean & Field Pea \\
\hline $\mathrm{pH}_{\text {water }}(1: 2.5)$ & 5.82 & 5.92 & 6.74 & 6.6 \\
Organic carbon (\%) & 0.2465 & 0.27 & 0.88 & 1.47 \\
Total N (\%) & 0.0695 & 0.067 & 0.074 & 0.102 \\
P-Olsen (mg kg ${ }^{-1}$ ) & 9.37 & 10.46 & 5.86 & 11.12 \\
CEC (meq/100 gm soil) & 15.4 & 31.10 & 50.2 & 53.6 \\
Clay (\%) & 17 & 34.00 & 42 & 56 \\
Silt (\%) & 12 & 13.00 & 35 & 23 \\
Sand (\%) & 71 & 53.00 & 23 & 21 \\
Textural Class & Sandy Loam & Sandy Loam & Clay & Clay \\
\hline
\end{tabular}

Yield Components: Plant Height and Head Length

Application of nitrogen fertilizer after different legume crops significantly influenced plant height and head length (Table 2 and 3). Effects of nitrogen rate after legume on plant height was not statistically significant after fababean and field pea at Emba Alaje. Plant height was increased with the increase in the application rates of $\mathrm{N}$ for wheat after chick pea and grass pea in Hawzien district. The tallest plants were obtained from the plots received nitrogen rate of $69 \mathrm{~kg} \mathrm{~N} \mathrm{ha}^{-1}$ after chick pea and grass pea in Hawzien. Head length was not influenced by different nitrogen rates after fababean at Emba Alaje, but was significant after grass pea, field pea and chickpea. Abreha (2013) and Bereket (2014) reported that plant height and head length of wheat increased with $\mathrm{N}$ application rate.

Table 2: Effect of nitrogen on wheat plant height after chickpea, grass pea, fababean and field pea precursor leguminous crops at Hawzien and Emba-Alaje districts

\begin{tabular}{ccccc}
\hline \multicolumn{5}{c}{ Plant Height (cm) } \\
\hline $\begin{array}{c}\text { Treatments } \\
\left(\mathbf{k g ~ N ~ h a}^{-1}\right)\end{array}$ & Chick Pea & Grass Pea & Fababean & Field Pea \\
\hline 0 & $75.5 \mathrm{~b}$ & $70.4 \mathrm{~b}$ & 86.3 & 96.4 \\
11.5 & $76.8 \mathrm{~b}$ & $73 \mathrm{ab}$ & 89.2 & 94.9 \\
23 & $78.8 \mathrm{ab}$ & $73.2 \mathrm{ab}$ & 87.9 & 95.1 \\
34.5 & $77.8 \mathrm{ab}$ & $75 \mathrm{ab}$ & 90.2 & 98.5 \\
46 & $82.2 \mathrm{a}$ & $78.6 \mathrm{a}$ & 91.5 & 95.3 \\
69 & $82.7 \mathrm{a}$ & $78.9 \mathrm{a}$ & 90.6 & 99 \\
\hline LSD & $\mathbf{5 . 1 7}$ & $\mathbf{6 . 1}$ & $\mathbf{7 . 6 N S}$ & $\mathbf{8 . 6 ~ N S}$ \\
CV (\%) & $\mathbf{5 . 5}$ & $\mathbf{6 . 9 6}$ & $\mathbf{7 . 2}$ & $\mathbf{7 . 6}$ \\
\hline
\end{tabular}


Table 3: Effect of nitrogen on wheat head length after chickpea, grass pea, fababean and field pea precursor leguminous crops at Hawzien and Emba-Alaje districts

\begin{tabular}{cllll}
\hline \multicolumn{5}{c}{ Head length (cm) } \\
\hline $\begin{array}{c}\text { Treatments } \\
\left.\text { (kg N ha }^{-1}\right)\end{array}$ & Chick pea & Grass pea & Fababean & Field pea \\
\hline 0 & $6.41 \mathrm{c}$ & $5.83 \mathrm{~b}$ & 7.2 & $7.2 \mathrm{ab}$ \\
11.5 & $6.46 \mathrm{bc}$ & $6.03 \mathrm{ab}$ & 9 & $7.3 \mathrm{ab}$ \\
23 & $6.86 \mathrm{a}$ & $6.05 \mathrm{ab}$ & 6.7 & $7.3 \mathrm{ab}$ \\
34.5 & $6.85 \mathrm{ab}$ & $6.12 \mathrm{ab}$ & 7.2 & $7.46 \mathrm{ab}$ \\
46 & $6.76 \mathrm{abc}$ & $6.18 \mathrm{ab}$ & 7.5 & $7.1 \mathrm{~b}$ \\
69 & $6.63 \mathrm{abc}$ & $6.46 \mathrm{a}$ & 7.7 & $7.8 \mathrm{a}$ \\
\hline LSD & $\mathbf{0 . 3 9}$ & $\mathbf{0 . 5 8}$ & $\mathbf{N S}$ & $\mathbf{0 . 6 4}$ \\
CV (\%) & $\mathbf{5 . 0 5}$ & $\mathbf{8 . 1}$ & $\mathbf{2 6 . 4}$ & $\mathbf{7 . 4}$ \\
\hline
\end{tabular}

\section{Yields}

There is a significant difference in grain and straw yields of wheat due to application of nitrogen after chick pea and grass pea crops rotation (Table 4 and 5). Grain and straw yields of wheat increase with an increase in nitrogen application. Indicating that there is need for application of nitrogen after chick pea and grass pea in the sandy soils of Hawzien. There is a significant difference in grain and straw yields of wheat due to application of nitrogen after fababean crop rotation (Table 4 and 5). Grain and straw yields of wheat increase with an increase of nitrogen application up to a rate of $46 \mathrm{~kg} \mathrm{~N}$ ha ${ }^{1}$ though it was not significant with the application rate of $34.5 \mathrm{~kg} \mathrm{~N} \mathrm{ha}{ }^{-1}$. Indicating that there is a need for application of nitrogen up to $34.5 \mathrm{~kg} \mathrm{~N} \mathrm{ha}^{-1}$ after fababean leguminous crop rotation. There is no significant difference in grain and straw yields of wheat due to application of nitrogen after field pea crop rotation (Table 4 and 5). The grain and straw yields of wheat after field pea crop rotation was highest than others, this may be due to the better initial soil nitrogen. Crop sequence with preceding crop such as grass pea, chick pea and fababean had little additional benefit of residual fertility from the proceeding leguminous crop, which when utilized in addition to the applied inorganic nitrogen and resulted exuberant crop growth, which ultimately resulted in increased biological yield. Maadi et al. (2012) stated that the preceding leguminous crop increases the grain yields of wheat significantly. Nehra et al. (2001) reported that nitrogen is a nutrient which enhances vegetative growth of the crop and have positive relationship with biological yield.

Table 4: Effect of nitrogen on wheat grain yield after chickpea, grass pea, fababean and field pea precursor leguminous crops at Hawzien and Emba-Alaje districts

\begin{tabular}{|c|c|c|c|c|}
\hline \multirow[b]{3}{*}{$\begin{array}{l}\text { Treatments } \\
\left(\mathrm{kg} \mathrm{N} \mathrm{ha}^{-1}\right)\end{array}$} & \multicolumn{4}{|c|}{ Grain yield $\left(\mathrm{kg} \mathrm{ha}^{-1}\right)$} \\
\hline & \multicolumn{2}{|c|}{ Hawzien } & \multicolumn{2}{|c|}{ Emba-Alaje } \\
\hline & Chick Pea & Grass Pea & Fababean & Field Pea \\
\hline 0 & $2433 b$ & $1825 d$ & $3633 d$ & 5569 \\
\hline 11.5 & 2442b & $2579 c d$ & $4108 d c$ & 6069 \\
\hline 23 & 2833b & $2475 c$ & 3983dc & 6792 \\
\hline 34.5 & $2875 b$ & $3096 b c$ & 4783ab & 6750 \\
\hline 46 & $3433 a$ & $3400 a b$ & $4892 a$ & 6236 \\
\hline 69 & $3500 a$ & $3750 a$ & $4292 b c$ & 6056 \\
\hline LSD & 457.8 & 566.3 & 581.3 & NS \\
\hline CV (\%) & 13.2 & 16.7 & 7.6 & 18.8 \\
\hline
\end{tabular}

Table 5: Effect of nitrogen on wheat straw yield after chickpea, grass pea, fababean and field pea precursor leguminous crops at Hawzien and Emba-Alaje districts

\begin{tabular}{ccccc}
\hline \multicolumn{4}{c}{ Straw yield (kgha-1) } \\
\hline \multicolumn{4}{c}{ Hawzien } & \multicolumn{2}{c}{ Emba-Alaje } \\
\hline $\begin{array}{c}\text { Treatments } \\
\left(\mathbf{k g ~ N ~ h a ~}^{-1}\right)\end{array}$ & Chick Pea & Grass Pea & Fababean & Field Pea \\
\hline 0 & $4117 \mathrm{~d}$ & $3275 \mathrm{~d}$ & 4208 & 6542 \\
11.5 & $4350 \mathrm{~cd}$ & $3883 \mathrm{~cd}$ & 5042 & 6861 \\
23 & $5125 \mathrm{~b}$ & $4325 \mathrm{~b} \mathrm{c}$ & 4817 & 7847 \\
34.5 & $4742 \mathrm{bc}$ & $4821 \mathrm{bc}$ & 5725 & 8264 \\
46 & $5825 \mathrm{a}$ & $5475 \mathrm{ab}$ & 5942 & 7097 \\
69 & $6242 \mathrm{a}$ & $6108 \mathrm{a}$ & 5383 & 6764 \\
\hline LSD & $\mathbf{6 2 4 . 7}$ & $\mathbf{9 7 9}$ & $\mathbf{8 8 3}$ & $\mathbf{N S}$ \\
CV (\%) & $\mathbf{1 0 . 4}$ & $\mathbf{1 7 . 7}$ & $\mathbf{9 . 4}$ & $\mathbf{1 9 . 3}$ \\
\hline
\end{tabular}


Bereket Haileselassie et al.,

Agronomic Nitrogen Efficiency of Wheat after Major Leguminous Crops

Agronomic efficiency is the amount of additional yield obtained for each additional kg of nutrient applied (Mengel and Kirkby, 2001). Agronomic efficiency showed inconsistent trend by applying different $\mathrm{N}$ rates after major leguminous crops. Relatively agronomic efficiency decreases with $\mathrm{N}$ rates (Table 6). In Hawzien the highest agronomic efficiency after chick pea and grass pea was recorded from plots treated with $46 \mathrm{~kg} \mathrm{~N} \mathrm{ha}^{-1}$ and $34.5 \mathrm{~kg}$ $\mathrm{N}$ ha ${ }^{-1}$,respectively. In Emba Alaje the highest agronomic efficiency after faba bean and field pea was obtained from
Sci. Technol. Arts Res. J., Jan-March 2016, 5(1): 9-15

plots treated with $11.5 \mathrm{~kg} \mathrm{~N} \mathrm{ha}^{-1}$ and $23 \mathrm{~kg} \mathrm{~N}^{-1}$, respectively. According to Dobermann (2005) if obtained agronomic efficiency results are above 30 , it could be concluded that the farm was under well managed system and reverse is true, if the results obtained are below the common values which is 10 to 30 . The result from Hawzien and Emba Alaje were nearly in line with Abebe (2012) and Dargie et al. (2016) reported that, AE of wheat decreases with N rates. Craswell and Godwin (1984) asserted that high agronomic efficiency could be obtained if the yield increment per unit $\mathrm{N}$ applied is high because of reduced losses and increased $\mathrm{N}$ uptake.

Table 6: Agronomic Nitrogen efficiency of Wheat after major leguminous crops

\begin{tabular}{|c|c|c|c|c|}
\hline \multicolumn{3}{|c|}{ Hawzien } & \multicolumn{2}{|c|}{ Emba Alaje } \\
\hline $\begin{array}{l}\text { Treatments } \\
\left(\mathrm{kg} \mathrm{N} \mathrm{ha}^{-1}\right)\end{array}$ & $\begin{array}{l}\text { AE of wheat } \\
\text { after chick pea } \\
(\mathrm{kg} / \mathrm{kg})\end{array}$ & $\begin{array}{l}\text { AE of wheat } \\
\text { after Grass pea } \\
(\mathrm{kg} / \mathrm{kg})\end{array}$ & $\begin{array}{c}\text { AE of wheat } \\
\text { After Fababean } \\
(\mathrm{kg} / \mathrm{kg})\end{array}$ & $\begin{array}{l}\text { AE of wheat } \\
\text { after Field pea } \\
\text { (kg / } / \mathrm{kg})\end{array}$ \\
\hline 0 & - & - & - & - \\
\hline 11.5 & 0.78 & 65.56 & 41.30 & 43.47 \\
\hline 23 & 17.39 & 28.260 & 15.21 & 53.17 \\
\hline 34.5 & 12.81 & 36.84 & 33.33 & 34.23 \\
\hline 46 & 21.73 & 34.23 & 27.36 & 14.5 \\
\hline 69 & 15.46 & 27.89 & 9.55 & 7.05 \\
\hline
\end{tabular}

Partial Budget Analysis of Nitrogen Rates after Major leguminous Crops

The results of marginal rate of return (MRR) of the Hawzien and Emba Alaje districts are presented in Tables 7, 8 and 9. At Hawzien, the partial budget analysis revealed that application of $46 \mathrm{~kg} \mathrm{~N}$ ha $^{-1}$ for bread wheat after chick pea and grass pea was economical with $1545 \%$ and $796 \%$ marginal rate of return, respectively. This implies that for each birr invested in the production of wheat, the farmers could earn birr 15.45 after chickpea and birr 7.96 after grass pea after recovering their cost of production.

At Emba Alaje, the partial budget analysis revealed that application of $34.5 \mathrm{~kg} \mathrm{~N}^{-1}$ for bread wheat after fababean was economical with $895 \%$ marginal rate of return. This implies that for each birr invested in the production of wheat, the farmers could earn birr 8.95 after fababean after recovering their cost of production.

According to the manual for economic analysis of CIMMYT (1988) the recommendation is not necessarily based on the treatment with the highest marginal rate of return compared to that of neither next lowest cost, the treatment with the highest net benefit, and nor the treatment with the highest yield. The identification of a recommendation is based on a change from one treatment to another if the marginal rate of return of that change is greater than the minimum rate of return (100\%). According to the marginal rate of return $46 \mathrm{~kg} \mathrm{Nha-1}$ and $34.5 \mathrm{~kg} \mathrm{~N} \mathrm{ha}^{-1}$ was found economically profitable compared to other treatments at Hawzien and Emba Alaje, respectively.

Table 7: Partial budget analysis of wheat after Chick pea

\begin{tabular}{|c|c|c|c|c|c|c|c|c|}
\hline $\begin{array}{l}\text { Fertilizer } \\
\text { rate } \\
\left(\begin{array}{c}k_{0} \mathbf{N} \\
1\end{array}\right)\end{array}$ & $\begin{array}{c}\text { Fertilizer } \\
\text { cost } \\
\text { (Birr) }\end{array}$ & $\begin{array}{c}\text { Fertilizer } \\
\text { application and } \\
\text { transport cost } \\
\text { (Birr) }\end{array}$ & $\begin{array}{c}\text { Total variable } \\
\text { cost } \\
\text { (TVC)[Birr] }\end{array}$ & $\begin{array}{l}\text { Grain } \\
\text { yield } \\
\text { (kgha-1 }\end{array}$ & $\begin{array}{c}\text { Total } \\
\text { Revenue (TR) } \\
\text { [Grain } \\
\text { yield*11 Birr] }\end{array}$ & $\begin{array}{l}\text { Net } \\
\text { Revenue } \\
\text { [TR-TVC] }\end{array}$ & $\begin{array}{l}\text { Marginal } \\
\text { Rate of } \\
\text { Return } \\
\text { (ratio) } \\
\end{array}$ & $\begin{array}{c}\text { Marginal } \\
\text { Rate of } \\
\text { Return } \\
(\%) \\
\end{array}$ \\
\hline 0 & 0 & 0 & 0 & 2442 & 26862 & 26862 & 0 & 0 \\
\hline 11.5 & 313 & 60 & 373 & 2433 & 26763 & 26390 & $\mathrm{D}$ & $\mathrm{D}$ \\
\hline 23 & 626 & 12 & 746 & 2833 & 31163 & 30417 & 4.765 & 476.5 \\
\hline 34.5 & 939 & 180 & 1119 & 2875 & 31625 & 30506 & D & D \\
\hline 46 & 1252 & 240 & 1492 & 3433 & 37763 & 36271 & 15.45 & 1545 \\
\hline 69 & 1878 & 300 & 2178 & 3500 & 38500 & 36322 & $\mathrm{D}$ & $\mathrm{D}$ \\
\hline
\end{tabular}

Table 8: Partial budget analysis of wheat after Grass pea

\begin{tabular}{ccccccccc}
\hline $\begin{array}{c}\text { Fertilizer } \\
\text { rate } \\
\mathbf{( k g ~ N ~ h a ~}^{-1} \text { ) }\end{array}$ & $\begin{array}{c}\text { Fertilizer } \\
\text { cost (Birr) }\end{array}$ & $\begin{array}{c}\text { Fertilizer } \\
\text { application \& } \\
\text { transport cost } \\
\text { (Birr) }\end{array}$ & $\begin{array}{c}\text { Total } \\
\text { variable } \\
\text { cost (TVC) } \\
\text { [Birr] }\end{array}$ & $\begin{array}{c}\text { Grain } \\
\text { yield } \\
\text { (kgha-1) }\end{array}$ & $\begin{array}{c}\text { Total Revenue } \\
\text { (TR) [Grain } \\
\text { yield*11 Birr] }\end{array}$ & $\begin{array}{c}\text { Net } \\
\text { Revenue } \\
\text { [TR-TVC] }\end{array}$ & $\begin{array}{c}\text { Marginal } \\
\text { Rate of } \\
\text { Return } \\
\text { (ratio) }\end{array}$ & $\begin{array}{c}\text { Marginal } \\
\text { Rate of } \\
\text { Return } \\
\text { (\%) }\end{array}$ \\
\hline 0 & 0 & 0 & 0 & 1825 & 20075 & 20075 & 0 & 0 \\
11.5 & 313 & 60 & 373 & 2579 & 28369 & 27996 & 21.23 & 2123 \\
23 & 626 & 12 & 746 & 2475 & 27225 & 26479 & $\mathrm{D}$ & $\mathrm{D}$ \\
34.5 & 939 & 180 & 1119 & 3096 & 34056 & 32937 & 6.62 & 662 \\
46 & 1252 & 240 & 1492 & 3400 & 37400 & 35908 & 7.96 & 796 \\
69 & 1878 & 300 & 2178 & 3750 & 41250 & 39072 & 4.61 & 461 \\
\hline
\end{tabular}


Table 9: Partial budget analysis of wheat after Faba bean

\begin{tabular}{|c|c|c|c|c|c|c|c|c|}
\hline $\begin{array}{l}\text { Fertilizer } \\
\quad \text { rate } \\
\left(\mathbf{k g ~ N ~ h a}^{-1}\right)\end{array}$ & $\begin{array}{c}\text { Fertilizer } \\
\text { cost } \\
\text { (Birr) }\end{array}$ & $\begin{array}{c}\text { Fertilizer } \\
\text { application \& } \\
\text { transport cost } \\
\text { (Birr) }\end{array}$ & $\begin{array}{c}\text { Total } \\
\text { variable } \\
\text { cost } \\
\text { (TVC)[Birr] }\end{array}$ & $\begin{array}{c}\text { Grain } \\
\text { yield } \\
\left(\text { kgha- }^{1}\right)\end{array}$ & $\begin{array}{c}\text { Total } \\
\text { Revenue (TR) } \\
\text { [Grain yield* } \\
11 \text { Birr] }\end{array}$ & $\begin{array}{c}\text { Net } \\
\text { Revenue } \\
\text { [TR-TVC] }\end{array}$ & $\begin{array}{l}\text { Marginal } \\
\text { Rate of } \\
\text { Return } \\
\text { (ratio) }\end{array}$ & $\begin{array}{l}\text { Marginal } \\
\text { Rate of } \\
\text { Return } \\
\text { (\%) }\end{array}$ \\
\hline 0 & 0 & 0 & 0 & 3633 & 39963 & 39963 & 0 & 0 \\
\hline 11.5 & 313 & 60 & 373 & 4108 & 45188 & 44815 & 13.00 & 1300 \\
\hline 23 & 626 & 12 & 746 & 3983 & 43813 & 43067 & D & $\mathrm{D}$ \\
\hline 34.5 & 939 & 180 & 1119 & 4783 & 52613 & 51494 & 8.95 & 895 \\
\hline 46 & 1252 & 240 & 1492 & 4892 & 53812 & 52320 & 2.21 & 221 \\
\hline 69 & 1878 & 300 & 2178 & 4292 & 47212 & 45034 & $\mathrm{D}$ & $\mathrm{D}$ \\
\hline
\end{tabular}

\section{CONCLUSIONS}

Grain and straw yields of wheat increased significantly with application of nitrogen after chick pea, grass pea and fababean precursor crops. Although the precursor crops were leguminous with nitrogen fixing ability nature, there was significant increase in grain and straw yields of wheat up to $46 \mathrm{~kg} \mathrm{~N} \mathrm{ha}^{-1}$. Both biological and partial budget analysis revealed that the optimum nitrogen rate after chickpea and grass pea was $46 \mathrm{~kg} \mathrm{~N} \mathrm{ha}^{-1}$ and after fababean $34.5 \mathrm{~kg} \mathrm{~N} \mathrm{ha}^{-1}$. There was no significant effect of nitrogen application for wheat after field pea indicating the precursor crop (field pea) had contributed for fixation of nitrogen in the soil.

\section{Conflict of Interest}

Conflict of interest none declared.

\section{Acknowledgments}

The authors thank Mekelle Soil Research Centre for financial and laboratory support.

\section{REFERENCES}

Abebe Getu (2012). Soil characterization and evaluation of slow release urea fertilizer rates on yield components and grain yields of wheat and teff on Vertisols of jamma district of south wollo zone, amhara region. MSc Thesis, Haramaya University, Haramaya, Ethiopia.

Abreha Kidanemariam., Heluf Gebrekidan., Tekalign Mamo., Kindie Tesfaye. (2013). Wheat Crop Response to Liming Materials and $\mathrm{N}$ and $\mathrm{P}$ Fertilizers in Acidic Soils of Tsegede Highlands, Northern Ethiopia. Agriculture, Forestry and Fisheries 2(3): 126-135.

Adrien N'Dayegamiye., Joann K. Whalen., Gilles Tremblay., Judith Nyiraneza., Michèle Grenier., Anne Drapeau and Marie Bipfubusa. (2015). The Benefi ts of Legume Crops on Corn and Wheat Yield,Nitrogen Nutrition, and Soil Properties Improvement. Agronomy Journal 107(5): 16531665.

Arshad, M.A., Gili, K.S. and Izaurralde, R. (1998). Wheat Production, Weed Population and Soil Properties Subsequent to 20 Years of Sod as Affected by Crop Rotation and Tillage. Journal of Sustainable Agriculture 12(2/3): 131-154.

Bauman, D.T., Kroff, M.J. and Bastiaans, L. (2000). Inter cropping leeks to suppress weeds. Weed Research 40: 359-374.

Bereket, H., Tjeerd, J.S. and Ellis H. (2011). Tef (Eragrostis tef) production constraints on Vertisols in Ethiopia: farmers' perceptions and evaluation of low soil zinc as yield-limiting factor. Journal of Soil Science and Plant Nutrition 57(4): 587-596.

Bereket Haileselassie., Dawit Habte., Mehretab Haileselassie., Gebremedhin Gebremeskel (2014). Effects of mineral nitrogen and phosphorus fertilizers on yield and nutrient utilization of bread wheat (Tritcum aestivum) on the sandy soils of Hawzen District, Northern Ethiopia. Agriculture, Forestry and Fisheries 3(3):189198.

Berhanu Debele (1980). The physical criteria and their rating proposed for land evaluation in the highland region of Ethiopia. Land Use Planning and Regulatory Department, Ministry of Agriculture, Addis Ababa, Ethiopia.

Black. C.A., Evans D.D., White J.L. Ensminger L.E., and Clark F.E.(1965). Method of Soil Analysis, Part 2. ASA, Inc. Madison, Wis, USA.

Bouyoucos J. (1962). Hydrometer method improved for making particle size analysis of soil. Agronomy Journal 54: 464-465.

Bremner, J.M. and Mulvaney C.S. (1982). Nitrogen - Total, Methods of soil analysis. Part 2-Chemical and microbiological properties. Agronomy 9(2):595-624.

CIMMYT (1988). From Agronomic Data to Farmer Recommendations: An Economics Training Manual. Completely revised edition. Mexico.

Craswell, E.T. and Godwin, D.C. (1984). The efficiency of nitrogen fertilizers applied to cereals in different climates, pp.124-140. In: Mengel, K. and E.A. Kirkby, 1996. Principles of Plant Nutrition. Panama Publishing Corporation, New Delhi, India.

Demeke, M. and Marcantonio Di F. (2013). Analysis of incentives and disincentives for wheat in Ethiopia. Technical notes series, MAFAP, FAO, Rome.

Dobermann, A. (2005). Nitrogen use efficiency state of art. IFA international workshop on enhanced efficiency fertilizers, Frankfurt, Germany.

Ethiopian Central Statistical Agency (CSA). (2013). The Federal Democratic Republic of Ethiopia Central Statistical Agency. Agricultural sample survey, report on area and production of major crops, Addis Ababa, Ethiopia.

FAO (Food and Agricultural Organization). (2000). Fertilizers and Their Use $4^{\text {th }}$ ed. International Fertilizer Industry Association, FAO, Rome, Italy.

Giller, K.E. (2001). Nitrogen Fixation in Tropical Cropping Systems. CAB International, Wallingford, UK, 423 pp. 


\section{Bereket Haileselassie et al.,}

Jackson, M.L. (1967). Soil Chemical Analysis. Prentice Hall of India Pvt. Ltd., New Delhi.

Landon, J.R. (1991). Booker Tropical Soil Manual: A hand book for soil survey and Agricultural Land Evaluation in the Tropics and Subtropics. Longman Scientific and Technical, Essex, New York. 474p. OR John Wiley and Sons Inc., New York.

Maadi, B., Fathi, G., Siadat, S.A., Alami Saeid, K. and Jafari, S. (2012). Effects of Preceding Crops and Nitrogen Rates on Grain Yield and Yield Components of Wheat (Triticum aestivum L.). World Applied Sciences Journal 17(10): 1331-1336.

Mengel, K. and Kirkby, E.A. (2001). Principles of Plant Nutrition, $5^{\text {th }}$ ed.; Kluwer Academic Publishers: Dordrecht, the Netherlands, pp. 481-509.

Nehra, A.S., Hooda, I.S. and Singh, K.P. (2001). Effect of integrated nutrient management on growth and yield of wheat (Triticum aestivum). Indian Journal of Agronomy 46(1): 112-117.
Sci. Technol. Arts Res. J., Jan-March 2016, 5(1): 9-15

Olsen R., Cole S., Watanabe F. and Dean L. (1954). Estimation of available phosphorus in soils by extraction with sodium bicarbonate. United States Department of Agriculture Circ. 939.

SAS. (2002). SAS/STAT User's Guide, Version 9.1.3. SAS institute Inc., Cary, NC.

Sofonyas Dargie., Lemma Wogi and Selamyihun Kidanu (2016). Response of Wheat on Uptake, Protein and Nitrogen Use Efficiency to Application of Slow Releasing Nitrogen Fertilizer in Northern Ethiopia. Asian Research Journal of Agriculture 2(1):1-8.

Tekalign Tadese (1991). Soil, plant, water, fertilizer, animal manure and compost analysis. Working Document No. 13. International Livestock Research Center for Africa, Addis Ababa.

Walkley, A. and Black I.A. (1934). An examination of the method for determining soil organic matter and proposed chromic acid titration method. Soil Science 37: 29-38. 